\title{
ASUPAN MAKAN DAN PROFIL LIPID PEGAWAI DENGAN STATUS GIZI NORMAL DAN OBESITAS
}

\section{DIETARY INTAKE AND LIPID PROFILE OF EMPLOYEES WITH NORMAL NUTRITIONAL STATUS AND OBESITY}

\author{
${ }^{1}$ Arinda Lironika Suryana, ${ }^{2}$ Zora Olivia \\ Progam Studi Rekam medik Jurusan Kesehatan, Politeknik Negeri Jember \\ Jln Mastrip Kotak Pos 164 Jember \\ 1arinda17md@gmail.com
}

\begin{abstract}
Abstrak
Obesitas merupakan masalah gizi dan kesehatan kronis karena prevalensinya yang terus meningkat dan menjadi faktor risiko dari penyebab kematian ke-lima di dunia. Obesitas adalah suatu keadaan penumpukan lemak berlebihan atau abnormal yang dapat menimbulkan gangguan kesehatan. Salah satu penyebab terjadinya obesitas adalah asupan makan sehari-hari yang berlebihan. Obesitas yang terjadi dalam jangka waktu lama akan berdampak pada perubahan profil lipid seperti kolesterol total, LDL dan HDL. Penelitian ini bertujuan untuk mengetahui perbedaan asupan makan dan profil lipid pegawai dengan status gizi normal dan obesitas di Politeknik Negeri Jember. Jenis penelitian ini observasional analitik dengan desain studi cross sectional. Penelitian dilaksanakan di Politeknik Negeri Jember. Sampel penelitian adalah pegawai yang bekerja di Politenik Negeri Jember dan berstatus PNS yang berumur $\geq 30$ tahun dan berjumlah 36 orang. Sampel dibagi kedalam dua kelompok yaitu status gizi normal dan obesitas. Teknik sampling dengan purposive sampling. Data asupan makan dikumpulkan dengan metode wawancara dan food recall, status gizi dengan pengukuran antropometri dan data profil lipid dengan pemeriksaan laboratorium. Data yang diperoleh dianalisis menggunakan Independent T-test dan Mann Whitney dengan signifikansi $\mathrm{p}=0,05$. Hasil penelitian ini menunjukkan tidak didapatkan perbedaan yang signifikan dari asupan karbohidrat $(\mathrm{p}=0,203 ; \mathrm{p}>0,05)$, protein $(\mathrm{p}=0,303 ; \mathrm{p}>0,05)$ dan serat $(\mathrm{p}=0,481 ; \mathrm{p}>0,05)$ pada kedua kelompok responden. Sedangkan, asupan energi $(p=0,002 ; p<0,05)$ dan lemak $(p=0,027 ; p<0,05)$ terdapat perbedaan yang signifikan antara responden dengan status gizi normal dan obesitas. Tidak didapatkan perbedaan kadar kolesterol total ( $\mathrm{p}=0,351)$, LDL $(\mathrm{p}=0,173)$ dan HDL $(\mathrm{p}=0,250)$ antara kelompok dengan status gizi normal dan obesitas.
\end{abstract}

Kata Kunci : Asupan Makan, Obesitas, Profil Lipid

\begin{abstract}
Obesity is a chronic nutrition and health problem because of the increased prevalence and become a risk factors fifth leading cause of death in the world. Obesity is a state of excessive or abnormal accumulation of fat that can cause health problems. One of the causes of obesity is excessive dietary intake. Obesity happens in the long term will affect the lipid profile changes such as total cholesterol, LDL and HDL. This study aims to determine differences in dietary intake and lipid profile of employees with normal nutritional status and obesity at the State Polytechnic of Jember. This research is analytic observational with cross sectional study design. Samples were employees in the State Polytechnic of Jember aged $\geq 30$ years and amounted to 38 people, divided into two groups are normal nutritional status and obesity. Sampling with purposive sampling technique. Dietary intake data were collected by interview and food recall, nutritional status data with anthropometric measurements and lipid profile data with laboratory tests. Data were analyzed using Independent T-test and Mann Whitney with significance $\mathrm{p}=0.05$. The results showed no significant difference obtained from carbohydrate intake $(\mathrm{p}=0.203 ; \mathrm{p}>0.05)$, protein $(\mathrm{p}=0.303 ; \mathrm{p}>0.05)$ and fiber $(\mathrm{p}=$ $0.481 ; p>0.05)$ in both groups of respondents. Meanwhile, there are significant differences of energy intake $(\mathrm{p}=0.002 ; \mathrm{p}<0.05)$ and fat intake $(\mathrm{p}=0.027 ; \mathrm{p}<0.05)$ between respondents with normal nutritional status and obesity. There were no differences in levels of total cholesterol $(\mathrm{p}=0.351)$, LDL $(\mathrm{p}=0.173)$ and HDL ( $\mathrm{p}$ $=0.250$ ) between respondents with normal nutritional status and obesity.
\end{abstract}

Key words : Dietary Intake, Lipid Profile, Obesity 


\section{PENDAHULUAN}

Obesitas menjadi pandemi global di seluruh dunia dan menjadi masalah gizi dan kesehatan kronis dengan konsekuensi yang sangat bervariasi mulai dari kematian, prematur sampai kualitas hidup yang rendah (Soegih, 2009). Prevalensi obesitas telah meningkat di seluruh dunia, baik di negara maju maupun negara berkembang. Menurut data WHO (2011), terdapat 1,6 miliar orang dewasa yang memiliki berat badan berlebih (overweight) dan 400 juta diantaranya mengalami obesitas. Data lain dilaporkan oleh American Heart Association/AHA pada tahun 2011, terdapat 12 juta $(16,3 \%)$ anak di Amerika yang berumur 2-19 tahun sebagai penyandang obesitas dan sekitar satu pertiga $(32,9 \%)$ atau 72 juta orang dewasa warga negara Amerika Serikat adalah obesitas (AHA, 2011). Sedangkan di Indonesia, hasil Riset Kesehatan Dasar tahun 2010 menunjukkan bahwa prevalensi obesitas berdasarkan Indeks Massa Tubuh (IMT) pada penduduk umur $\geq 18$ tahun sebesar $21,7 \%$ (10\% berat badan lebih dan $11,7 \%$ obesitas). Angka ini meningkat jika dibandingkan dengan hasil Riset Kesehatan Dasar tahun 2007 yang menunjukkan prevalensi nasional obesitas sebesar 10,3\% (laki-laki 13,9\%, perempuan 23,8\%) (Depkes RI, 2009). Angka obesitas pada laki-laki tahun 2010 sekitar $15 \%$ dan sekarang meningkat menjadi 20\% (Riskesdas, 2013).

Menurut data WHO (2013), obesitas merupakan risiko kematian ke-lima di dunia. Setidaknya 2,8 juta orang meninggal setiap tahun sebagai akibat dari kelebihan berat badan atau obesitas. Selain itu, obesitas menyebabkan risiko timbulnya berbagai macam penyakit seperti Diabetes Mellitus (44\%), penyakit jantung iskemik (23\%) dan kanker (7-41\%).

Istilah obesitas mengacu pada suatu keadaan dimana kelebihan lemak disimpan dalam jaringan adiposa (Seidell, JC ; Visscher, T, 2009). Obesitas juga didefinisikan sebagai penimbunan lemak tubuh berlebih yang tidak normal dan dapat menimbulkan dampak negatif bagi kesehatan (WHO, 2011). Metode yang paling umum digunakan dalam mengidentifikasi obesitas dalam praktik klinis adalah Indeks Massa Tubuh (IMT), ketebalan lipatan kulit dan impedans bioelektrik (Bandini, 2015). IMT memang bukan indikator terbaik untuk obesitas tetapi dapat digunakan sebagai alat screening internasional yang direkomendasikan untuk penilaian obesitas yang dapat mengakibatkan masalah kesehatan (CDC, 2011). IMT didefinisikan sebagai berat badan dalam kilogram dibagi dengan tinggi badan dalam meter kuadrat (Bandini, 2015). Seseorang dikatakan mengalami obesitas jika Indeks Massa
Tubuh (IMT) lebih dari $25 \mathrm{~kg} / \mathrm{m}^{2}$ (Heryudarini, 2005; Effendi, 2013).

Penelitian menunjukkan bahwa IMT, meskipun bukan pengukuran obesitas secara langsung, namun berkorelasi bermakna dengan lemak yang terdapat dalam tubuh yang diukur dengan metode laboratorium dan relatif tidak dipengaruhi oleh tinggi badan (Bandini, 2015).

Obesitas terjadi akibat dari ketidakseimbangan energi jangka panjang, yaitu asupan energi lebih besar daripada pengeluaran energi. Pengaturan keseimbangan energi diperankan oleh hipotalamus melalui 3 proses fisiologis, yaitu pengendalian rasa lapar dan kenyang, pengaturan pengeluaran energi dan pengaturan penyimpanan energi yang melibatkan regulasi sekresi hormon (Hidayat, 2008).

Etiologi obesitas bersifat kompleks dan dapat berasal dari faktor genetik, metabolik, perilaku dan lingkungan. Perubahan gaya hidup, termasuk makanan di luar rumah yang semakin mudah diperoleh, ukuran porsi serta ketersediaan makanan tinggi energi dan rendah gizi yang semakin meningkat, dapat menyebabkan peningkatan asupan energi. Beberapa bentuk pola makan yang dapat meningkatkan asupan energi telah menjadi fokus penelitian, seperti diet tinggi lemak, densitas energi tinggi, indeks glikemik tinggi dan rendah serat. Diet tinggi lemak memang banyak ditargetkan menjadi penyebab kelebihan asupan energi karena kepadatan energi dan palabilitas yang tinggi pada lemak (Bandini, 2015).

Terdapat tiga zat gizi makro, yaitu karbohidrat, protein dan lemak yang dapat memberikan energi untuk kebutuhan metabolisme. Tubuh manusia memiliki kapasitas penyimpanan kelebihan karbohidrat yang terbatas, kapasitas penyimpanan kelebihan protein yang kurang dan kapasitas penyimpanan kelebihan lemak yang besar sehingga kelebihan asupan karbohidrat dan protein akan dioksidasi terutama menjadi lemak. Jadi, oksidasi lemak berkurang dan kelebihan lemak disimpan. Ketika asupan energi lebih besar daripada pengeluaran energi, simpanan lemak tubuh akan meningkat (Bandini, 2015).

Mekanisme patofisiologis obesitas menempat kan sel lemak sebagai pusat kelainan berasal, tetapi tidak seluruhnya dapat dijelaskan. Meskipun begitu, telah ada bukti yang mengaitkan patogenesis obesitas dengan mekanisme sinyal di usus, jaringan lemak, otak dan mungkin jaringan lain tempat masuknya, penyebaran serta penyimpanan zat-zat gizi (Arisman, 2010).

Pertambahan massa lemak selalu disertai perubahan fisiologis tubuh yang sebagian besar bergantung pada distribusi massa lemak tersebut (Arisman, 2010). Berdasarkan distribusi lemak, obesitas dibagi menjadi obesitas umum dan 
obesitas sentral. Obesitas sentral (visceral obesity) merupakan kondisi akumulasi lemak yang terpusat di bagian perut (intra-abdominal fat) (Wirjatmadi, Bambang; Adriani, Merryana, 2012).

Obesitas umum (generalized obesity) mengakibatkan perubahan volume darah total serta fungsi jantung sedangkan obesitas sentral yang ditandai dengan penambahan ukuran lingkar pinggang, akan menimbulkan risiko sindroma metabolik yang meliputi hipertensi, peningkatan insulin plasma, sindroma resistensi insulin, hipertrigliseridemia dan dislipidemia (Arisman, 2010). Mekanisme dasar bagaimana komponenkomponen sindrom metabolik ini dapat terjadi pada seseorang dengan obesitas sentral dan bagaimana komponen-komponen ini dapat menyebabkan terjadinya gangguan vaskular, hingga saat ini masih dalam penelitian (Sugondo, 2007).

Beberapa mekanisme telah ditujukan untuk memainkan peran pada peningkatan produksi kolesterol hati yang terlihat pada obesitas sentral. Akibat beberapa mekanisme ini yang merupakan akibat dari penimbunan lemak dalam jangka panjang sehingga menyebabkan terjadinya peningkatan kadar kolesterol dalam darah (Subramanian, 2011)

Obesitas sentral merupakan karakteristik pengidap dislipidemia terutama tipe aterogenik. Bentuk dislipidemia yang lazim terdiri atas tiga kelainan lipid yang khas yaitu peningkatan kadar trigliserid, peningkatan LDL dan penurunan HDL (Arisman, 2010).

Penelitian yang dilakukan Zelzer dkk (2011) tentang hubungan obesitas dengan dislipidemia menunjukkan bahwa obesitas berhubungan dengan dislipidemia. Obesitas apabila menetap selama periode waktu tertentu bisa menyebabkan terjadinya berbagai gangguan metabolik dan diantaranya hiperkolesterolemia.

Sebuah penelitian yang dilakukan oleh Hastuti, dkk (2011), menunjukkan bahwa tidak terdapat perbedaan bermakna profil lipid antara subyek obesitas dengan kontrol ( $p>0,05)$. Penelitian lain (Laurentia, 2012) melaporkan hal yang berbeda yaitu, terdapat perbedaan kadar LDL antara subyek obesitas dan non obesitas. Kedua penelitian ini tidak meneliti tentang asupan zat gizi yang mungkin saja bisa terkait dengan profil lipid pada obesitas.

Mengingat bahaya keadaan obesitas dan dislipidemia, maka penting dilakukan pencegahan sejak dini dengan cara memantau asupan makanan serta melakukan penimbangan berat badan dan pemeriksaan profil lipid secara periodik. Dengan memperhatikan hal tersebut, peneliti tertarik untuk mengamati perbedaan asupan makan dan profil lipid pada pegawai yang memiliki status gizi normal dan obesitas di Politeknik Negeri Jember.

\section{METODOLOGI}

Penelitian ini merupakan jenis penelitian observasional analitik dengan desain studi cross sectional. Tujuannya untuk mengetahui perbedaan asupan makan dan profil lipid pegawai dengan status gizi normal dan obesitas. Penelitian dilakukan di Politeknik Negeri Jember pada bulan Agustus sampai Oktober tahun 2016. Pemeriksaan laboratorium dilakukan di Laboratorium PROSENDA.

Populasi dalam penelitian ini adalah seluruh Pegawai Negeri Sipil yang bekerja di Politeknik Negeri Jember. Sampel yang diambil sejumlah 36 orang dengan metode purposive sampling. Kriteria inklusinya berumur $\geq 30$ tahun, memiliki IMT $>25$ $\mathrm{kg} / \mathrm{m}^{2}$ untuk kelompok obesitas dan IMT $\geq 18,5$ $25 \mathrm{~kg} / \mathrm{m}^{2}$ untuk kelompok normal. Responden kemudian dibagi masing-masing 18 orang kelompok obesitas dan 18 orang status gizi normal.

Data penelitian dikumpulkan dengan teknik wawancara, kuesioner, antropometri, food recall 1x24 jam dan pemeriksaan laboratorium. Teknik wawancara dilakukan untuk mendapatkan data tentang karakteristik responden meliputi umur dan jenis kelamin. Data status gizi diperoleh dengan melakukan pengukuran antropometri (berat badan dan tinggi badan) kemudian dihitung IMT (Indeks Massa Tubuh). Sedangkan data asupan makan didapatkan melalui metode wawancara dan food recall 1x24 jam yang dilakukan sebanyak 2 kali (Gibson, 2005). Selanjutnya, masing-masing kelompok akan diambil sampel darahnya sebanyak $5 \mathrm{ml}$ untuk kemudian diukur profil lipid. Pengukuran profil lipid meliputi pemeriksaan kolesterol total, $L D L, H D L$ dalam darah dengan metode $C H O D-P A P$. Pengukuran profil lipid darah ini dilakukan dalam keadaan puasa kurang lebih 8 jam. Pengambilan sampel darah dilakukan oleh petugas khusus dari laboratorium PROSENDA Jember.

Data diolah dengan SPSS versi 16.00 dan dianalisis menggunakan Independen T-test dan Mann Whitney. Sebelumnya, terlebih dahulu dilakukan pengujian normalitas data dengan Shapiro-Wilks sebagai salah satu persyaratan menetukan uji.

\section{HASIL DAN PEMBAHASAN}

\section{A. Karakteristik Responden}

Penelitian ini melibatkan 36 orang responden yang terdiri dari 18 orang termasuk dalam kelompok status gizi normal dan 18 orang termasuk dalam kelompok obesitas. Dari pengukuran status gizi dengan metode antropometri menggunakan indikator IMT didapatkan rata-rata IMT pada kelompok dengan 
status gizi normal yaitu $20,62 \pm 1,62 \mathrm{~kg} / \mathrm{m}^{2}$. Sedangkan pada kelompok obesitas, didapatkan rata-rata IMT yaitu $29,02 \pm 4,54 \mathrm{~kg} / \mathrm{m}^{2}$. Status gizi dalam kategori normal jika IMT $18,5-25,0 \mathrm{~kg} / \mathrm{m}^{2}$ dan obesitas jika IMT $>25 \mathrm{~kg} / \mathrm{m}^{2}$ (Heryudarini, 2005; Kemenkes RI, 2013).

Tabel 1.Karakteristik responden penelitian

\begin{tabular}{|c|c|c|c|}
\hline \multirow[b]{2}{*}{$\begin{array}{c}\text { Karakteristi } \\
\text { k }\end{array}$} & \multicolumn{2}{|c|}{ Kelompok } & \\
\hline & $\begin{array}{l}\text { Status gizi } \\
\text { normal } \\
(\mathrm{n}=18)\end{array}$ & $\begin{array}{l}\text { obesitas } \\
(\mathrm{n}=18)\end{array}$ & $\mathrm{p}$ \\
\hline $\begin{array}{l}\text { Jenis } \\
\text { Kelamin } \\
\text { laki-laki } \\
\text { perempu } \\
\text { an } \\
\end{array}$ & $\begin{array}{l}9(50 \%) \\
9(50 \%)\end{array}$ & $\begin{array}{l}9(50 \%) \\
9(50 \%)\end{array}$ & $\begin{array}{l}1, \\
00 \\
0^{\mathrm{a}}\end{array}$ \\
\hline $\begin{array}{l}\text { Umur } \\
\text { (th) }\end{array}$ & $43,89 \pm 7,29$ & $44,50 \pm 7,30$ & $\begin{array}{l}0, \\
80 \\
3^{\mathrm{b}}\end{array}$ \\
\hline
\end{tabular}

Keterangan : ${ }^{\mathrm{a}}$ Fisher exact test ${ }^{\mathrm{b}}$ Independent $\mathrm{t}$ test

Berdasarkan tabel diatas dapat dilihat bahwa rata-rata umur responden yang memiliki status gizi normal adalah 43,89 $\pm 7,29$ tahun. Sedangkan pada kelompok obesitas, rata-rata umur responden adalah 44,50 $\pm 7,30$ tahun. Dari hasil uji Independent $T$-Test diperoleh nilai $\mathrm{p}$-value $=0,803$ ( $\mathrm{p}<0,05$ ) yang artinya tidak terdapat perbedaan dari umur responden antara kelompok dengan status gizi normal dan obesitas.

\section{B. Asupan Makan}

Asupan makan adalah semua jenis makanan dan minuman yang dikonsumsi tubuh setiap hari yang diperoleh dengan metode Food Recall 1x24 jam sebanyak 2 kali dalam hari yang tidak berurutan. Responden akan diwawancarai terkait bahan makanan yang dikonsumsi dengan satuan ukuran rumah tangga (URT) dan selanjutnya akan dikonversikan ke dalam satuan gram. Adapun hasil analisis terhadap asupan makan responden disajikan dalam tabel 2.

Tabel 2 Perbedaan asupan makan pada kedua kelompok responden penelitian

\begin{tabular}{|l|c|c|c|}
\hline Variabel & $\begin{array}{c}\text { Status Gizi } \\
\text { Normal } \\
(\mathbf{n = 1 8})\end{array}$ & $\begin{array}{c}\text { Obesitas } \\
(\mathbf{n = 1 8})\end{array}$ & $\mathbf{p}$ \\
\hline $\begin{array}{l}\text { Asupan } \\
\text { energi (kal) }\end{array}$ & $\begin{array}{c}1704,66 \pm \\
189,47\end{array}$ & $\begin{array}{c}1932,11 \pm \\
208,80\end{array}$ & $0,002^{\mathrm{a}^{*}}$ \\
\hline $\begin{array}{l}\text { Asupan } \\
\text { karbohidrat } \\
\text { (gr) }\end{array}$ & $\begin{array}{c}236,22 \pm \\
49,14\end{array}$ & $\begin{array}{c}253,71 \pm \\
37,31\end{array}$ & $0,203^{\mathrm{b}}$ \\
\hline $\begin{array}{l}\text { Asupan } \\
\text { Protein (gr) }\end{array}$ & $\begin{array}{c}52,50 \pm \\
13,23\end{array}$ & $\begin{array}{c}57,04 \pm \\
12,82\end{array}$ & $0,303^{\mathrm{a}}$ \\
\hline $\begin{array}{l}\text { Asupan } \\
\text { Lemak (gr) }\end{array}$ & $\begin{array}{c}64,39 \pm \\
14,38\end{array}$ & $\begin{array}{c}75,43 \pm \\
12,07\end{array}$ & $0,027^{\mathrm{b}^{*}}$ \\
\hline
\end{tabular}

\begin{tabular}{l|c|c|c|}
\hline $\begin{array}{l}\text { Asupan } \\
\text { Serat }(g r)\end{array}$ & $17,75 \pm 7,18$ & $15,76 \pm 7,57$ & $0,481^{\mathrm{b}}$ \\
\hline
\end{tabular}
Keterangan : ${ }^{\mathrm{a}}$ Independent t-test ${ }^{\mathrm{b}}$ Mann Whitney
${ }^{*}$ signifikansi $\mathrm{p}<0,05$

Berdasarkan tabel 2, hasil penelitian menunjukkan rata-rata asupan energi, karbohidrat, protein dan lemak lebih tinggi pada kelompok responden yang obesitas daripada kelompok responden dengan status gizi normal. Sebaliknya, asupan serat lebih tinggi pada responden dengan status gizi normal.

Rata-rata asupan energi, karbohidrat, protein dan serat kedua kelompok responden masih dibawah Angka Kecukupan Gizi (2013) menurut jenis kelamin dan berat badan. Sedangkan rata-rata asupan lemak responden obesitas melebihi Angka Kebutuhan Gizi (Kemenkes, 2013).

Setelah dilakukan uji analisis statistik bivariat tidak didapatkan perbedaan yang signifikan dari asupan karbohidrat $(p=0,203 ; p>0,05)$, protein $(p=$ $0,303 ; p>0,05)$ dan serat $(p=0,481 ; p>0,05)$ pada kedua kelompok responden. Hanya asupan energi $(\mathrm{p}=0,002 ; \mathrm{p}<0,05)$ dan asupan lemak $(\mathrm{p}=0,027$; $p<0,05)$ yang memiliki perbedaan yang signifikan antara responden dengan status gizi normal dan obesitas.

Obesitas merupakan suatu kelainan kompleks pengaturan nafsu makan dan metabolisme energi yang dikendalikan oleh beberapa faktor biologik spesifik (Sudoyo, 2009). Faktor-faktor yang berpengaruh dari asupan makan terhadap terjadinya obesitas adalah kuantitas, porsi perkali makan, kepadatan energi dari makanan yang dimakan, kebiasaan makan, frekuensi makan dan jenis makanan (Soegih, 2009).

Terjadinya obesitas merupakan dampak dari masukan energi (energy intake) yang melebihi pengeluaran energi (energy expenditure) oleh tubuh sehingga kelebihan asupan energi disimpan dalam bentuk lemak. Ketidakseimbangan energi kecil yang dipertahankan dalam jangka waktu panjang dapat menyebabkan peningkatan berat badan yang cukup besar (Bandini, 2015). Kelebihan energi setiap hari secara rutin pada remaja dapat menimbulkan timbunan lemak tubuh menjadi bertambah (Goran,2006).

Makanan merupakan sumber dari asupan energi. Di dalam makanan yang akan diubah menjadi energi adalah zat gizi penghasil energi yaitu karbohidrat, protein dan lemak (Soegih, 2009).

Pada individu dengan status gizi normal, terjadi keseimbangan energi. Makanan yang diterima mengandung polisakarida (karbohidrat), lemak dan protein yang merupakan sumber energi atau penghasil ATP. Selanjutnya akan mengalami proses metabolisme. Lemak dihidrolisis (dipecah) 
menjadi asam lemak dan gliserol, polisakarida menjadi heksosa dan pentosa dan protein menjadi asam amino. Ketiganya menyediakan energi melalui siklus krebs. Energi tersebut kemudian digunakan oleh berbagai sistem fungsional sel (Effendi, 2013)

Peran utama karbohidrat di dalam tubuh adalah menyediakan glukosa bagi sel-sel tubuh, yang kemudian diubah menjadi energi. Kelebihan glukosa akan disimpan di dalam hati dan otot dalam bentuk glikogen. Tubuh hanya dapat menyimpan glikogen dalam jumlah terbatas. Jika asupan karbohidrat melebihi kapasitas oksidatif tubuh dan penyimpanan, sel dapat mengubah karbohidrat menjadi lemak. Perubahan ini terjadi di dalam hati. Lemak ini kemudian dibawa ke sel-sel lemak yang dapat menyimpan cadangan lemak dalam jumlah yang tidak terbatas (DeBruyne, 2011; Effendi, 2013).

Menurut Almatsier (2010), protein selain sumber energi juga memiliki fungsi yang tidak dapat digantikan oleh zat gizi lain yaitu membangun serta memelihara sel-sel jaringan tubuh. Protein dalam makanan dipecah menjadi asam amino yang setelah diserap akan mengisi hati dan otot, menggantikan protein yang dipecah sejak jam makan sebelumnya. Asam amino yang tidak dibutuhkan untuk sintesis protein akan dilepas dari gugus aminonya untuk membentuk urea dan residu karbohidrat yang digunakan hati untuk energi/sintesis lemak atau pembentukan glukosa baru (Effendi, 2013). Dalam keadaan berlebihan, protein akan mengalami deaminase atau pelepasan gugus amino $\left(\mathrm{NH}^{2}\right)$ dari asam amino. Nitrogen dikeluarkan dari tubuh dan sisa-sisa ikatan karbon akan diubah menjadi asetil KoA, suatu metabolit yang kaya energi. Oleh karena itu, bila seseorang mengkonsumsi banyak protein dalam makanannya dari yang dapat digunakan jaringannya, sebagian besar dari jumlah yang berlebihan ini disimpan sebagai lemak (Almatsier, 2010).

Makanan yang tinggi protein biasanya tinggi lemak sehingga dapat menyebabkan obesitas. Menurut Mestuti dan Fitranti (2014) kelebihan asupan dalam tubuh termasuk asupan protein akan disimpan berupa lemak. Tingginya konsumsi protein hewani pada responden dengan obesitas berkorelasi dengan rendahnya zat gizi hewan pada umumnya yang mengandung lemak jenuh dan kolesterol yang tinggi. Bila kondisi ini terjadi dalam jangka waktu yang lama, maka risiko untuk terjadinya obesitas makin meningkat (Kartika, S; Siti, R., 2012).

Kelebihan lemak akan disimpan di jaringan adiposit dan bila berlangsung terus menerus penumpukan lemak ini akan menimbulkan obesitas (Berdanier, 2008). Selain itu, penyebab utama terjadinya obesitas adalah ketidakseimbangan antara asupan energi dengan pengeluaran energi. Untuk setiap kelebihan energi sebanyak 9,3 kalori yang masuk ke tubuh, kira-kira 1 gram lemak akan disimpan. Lemak juga menghasilkan lebih banyak energi jika dibandingkan karbohidrat atau protein. Setelah makan, lemak dikirim ke jaringan adiposa untuk disimpan sampai dibutuhkan sebagai energi. Lemak disimpan terutama pada jaringan subkutan dan rongga intraperitoneal, walaupun hati dan jaringan tubuh lainnya seringkali menimbun cukup lemak pada orang obesitas. Perkembangan obesitas pada orang dewasa juga terjadi akibat penambahan jumlah adiposit dan peningkatan ukurannya. Seseorang dengan obesitas yang ekstrim dapat memiliki adiposit sebanyak empat kali normal, dan setiap adiposit memiliki lipid dua kali lebih banyak dari orang yang kurus (Guyton and Hall, 2010). Oleh karena itu kelebihan asupan lemak dari makanan dapat dengan mudah menambah berat badan.

Konsumsi serat yang cukup dapat menurunkan risiko obesitas dan kadar kolesterol darah orang dewasa. Makanan tinggi serat umumnya memerlukan waktu lebih banyak untuk mengunyah dan mencerna. Makanan yang mengandung serat tidak larut tidak dicerna dan menambah volume makanan, sehingga mengurangi risiko konsumsi yang berlebihan. Sedangkan serat larut air akan berubah menjadi substansi menyerupai gel selama proses pencernaan dan memperlambat makanan melewati usus sehingga membuat tubuh kenyang lebih lama. Disamping itu, serat jenis ini juga berkhasiat memperlambat pengosongan lambung serta penyerapan glukosa (Arisman, 2010).

\section{Profil Lipid}

Profil lipid yang diteliti hanya meliputi kolesterol total, LDL dan HDL. Sampel yang digunakan adalah darah vena responden yang diambil pada saat puasa minimal 8 jam. Adapun hasil analisis terhadap profil lipid responden disajikan dalam tabel 3.

Tabel 3. Perbedaan Profil Lipid Pada Kedua Kelompok Responden Penelitian

\begin{tabular}{|c|c|c|c|}
\hline $\begin{array}{c}\text { Profil } \\
\text { Lipid }\end{array}$ & $\begin{array}{c}\text { Status Gizi } \\
\text { Normal } \\
(\mathbf{n = 1 8})\end{array}$ & $\begin{array}{c}\text { Obesitas } \\
(\mathbf{n = 1 8})\end{array}$ & $\mathbf{p}$ \\
\hline $\begin{array}{c}\text { Kolesterol } \\
\text { total }(\mathrm{g} / \mathrm{dl})\end{array}$ & $191,22 \pm$ & $208,17 \pm$ & $0,351^{\mathrm{b}}$ \\
\hline LDL (g/dl) & 33,24 & 34,35 & \\
\hline HDL (g/dl) & $46,17 \pm 12,74$ & $41,89 \pm 8,82$ & $0,250^{\mathrm{a}}$ \\
\hline
\end{tabular}

Keterangan : ${ }^{\mathrm{a}}$ Independent t-test ${ }^{\mathrm{b}}$ Mann Whitney * signifikansi $\mathrm{p}<0,05$ 
Berdasarkan tabel diatas, dapat dilihat bahwa rata-rata kadar kolesterol total dan LDL pada kelompok responden obesitas lebih tinggi dibandingkan dengan responden yang memiliki status gizi normal. Sebaliknya rata-rata kadar HDL lebih tinggi pada responden yang tidak obesitas atau berstatus gizi normal.

Kadar kolesterol total responden dengan status gizi normal termasuk ideal sedangkan kadar kolesterol responden obesitas termasuk dalam batas tinggi. Kadar kolesterol dikatakan ideal jika $<200 \mathrm{mg} / \mathrm{dl}$ dan dalam batas tinggi jika 200-239 mg/dl. Sedangkan kadar LDL kedua kelompok responden termasuk dalam batas tinggi. Kadar LDL dikatakan normal jika $<130 \mathrm{gr} / \mathrm{dl}$, batas tinggi jika 130-159 gr/dl dan tinggi jika $\geq 160 \mathrm{mg} / \mathrm{dl}$. Semua responden baik yang obesitas maupun yang status gizinya normal memiliki kadar HDL normal. Kadar HDL pada orang normal berkisar antara 40$60 \mathrm{~g} / \mathrm{dl}$ (NHLBI, 2004)

Namun setelah dilakukan uji analisis statistik dengan Independent t-test dan Mann Whitney tidak didapatkan perbedaan kadar kolesterol total $(\mathrm{p}=0,351)$, LDL $(\mathrm{p}=0,173)$ dan HDL $(\mathrm{p}=0,250)$ antara kelompok responden dengan status gizi normal dan obesitas.

Faktor-faktor yang mempengaruhi kadar kolesterol dalam darah meliputi, peningkatan jumlah kolesterol yang dicerna, diet lemak yang sangat jenuh, diet tinggi asam lemak tak jenuh, kekurangan insulin atau hormon tiroid dan kelainan genetik (Guyton and Hall, 2010).

Diet tinggi lemak jenuh dapat meningkatkan kadar kolesterol darah $15-25 \%$ terutama jika disertai penambahan berat badan berlebih dan obesitas. Hal ini terjadi akibat peningkatan akumulasi lemak di hati yang kemudian menyebabkan peningkatan asetil-koA di dalam sel hati untuk menghasilkan kolesterol. Oleh itu, untuk menurunkan kadar kolesterol darah penting untuk membatasi asupan lemak jenuh dan mempertahankan asupan rendah kolesterol. Sedangkan diet tinggi asam lemak tidak jenuh mampu menurunkan kadar kolesterol darah namun mekanismenya masih belum diketahui secara pasti (Guyton dan Hall, 2010).

Obesitas yang menetap selama periode waktu tertentu, akibat energi yang masuk melalui makanan lebih banyak dapat menyebabkan terjadinya gangguan metabolik berupa hiperkolesterolemia. Pengaturan metabolisme kolesterol akan berjalan normal apabila jumlah kolesterol dalam darah mencukupi kebutuhan dan tidak melebihi jumlah normal yang dibutuhkan. Namun pada obesitas dikatakan dapat terjadinya gangguan pada regulasi asam lemak yang akan meningkatkan kadar kolesterol. Peningkatan kolesterol darah juga dapat disebabkan oleh kenaikkan kolesterol yang terdapat pada verylowdensity lipoprotein dan low-density lipoprotein sekunder karena peningkatan trigliserida yang besar dalam sirkulasi apabila terjadi penumpukan lemak berlebihan didalam tubuh (Guyton and Hall, 2010).

Asupan serat sebanyak 25-35 gram sehari dianjurkan bagi orang dewasa (Arisman, 2010). Pada penelitian ini rata-rata asupan serat responden hanya berkisar 15-17 gram, masih kurang dari kebutuhan sehari. Diet tinggi serat sangat bermanfaat untuk menyusutkan asupan kalori, lemak dan gula serta menurunkan kadar kolesterol. Serat larut air mampu mengikat asam empedu yang mengandung kolesterol di dalam saluran cerna, mencegah reabsorbsi kolesterol dan pertambahan kadar kolesterol dalam darah (Arisman, 2010).

Hasil penelitian ini sejalan dengan penelitian Hanif, dkk (2013) yang menunjukkan tidak terdapat perbedaan bermakna antara kadar kolesterol HDL darah pada wanita yang obes dan yang non-obes $(P=0,974)$. Namun, tidak sejalan dengan penelitian yang dilakukan oleh Hodoglogil, dkk (2005) yang menyatakan bahwa nilai IMT yang tinggi menunjukkan adanya hubungan dengan penurunan kadar HDL darah

Menurut Jorgensen et all (2006), pada seseorang dengan IMT obes memiliki kadar HDL cenderung tinggi dikarenakan pola hidup orang tersebut mengkonsumsi tinggi daging ikan (pola konsumsi Greenlandic). Kandungan PUFA (Poly Unsaturated Fatty Acid) omega-3 dalam daging ikan tersebut akan mempengaruhi aktifitas metabolik pada jaringan adiposa sehingga menyebabkan peningkatan kadar HDL.

\section{KESIMPULAN}

Kesimpulan yang didapat dari penelitian ini bahwa rata-rata asupan energi, karbohidrat, protein dan lemak kelompok obesitas lebih tinggi daripada kelompok responden dengan status gizi normal. Rata-rata asupan serat kelompok obesitas lebih rendah daripada kelompok responden dengan status gizi normal. Berdasarkan hasil uji statistik Independent T-test dan Mann Whitney diketahui bahwa tidak ada perbedaan yang bermakna asupan protein, karbohidrat, dan serat antara responden dengan status gizi normal dan obesitas. Ada perbedaan yang bermakna asupan energi dan lemak antara responden dengan status gizi normal dan obesitas. Sedangkan rata-rata profil lipid baik kolesterol total, LDL dan HDL tidak menunjukkan perbedaan yang bermakna antara responden dengan status gizi normal dan obesitas. Namun secara rata-rata kolesterol total dan LDL pada responden obesitas lebih tinggi daripada responden 
yang status gizinya normal. Sebaliknya kadar HDL pada responden obesitas lebih rendah dibanding responden yang status gizinya normal.

Perlu adanya penyuluhan gizi seimbang mengenai obesitas yang dikemas secara menarik sehingga diharapkan para pegawai akan mengetahui dampak dari obesitas dan dapat merubah kebiasaan makan yang sesuai dengan pedoman gizi seimbang.

\section{UCAPAN TERIMA KASIH}

Ucapan terima kasih disampaikan kepada Politenik Negeri Jember atas dukungan pendanaan DIPA Politeknik Negeri Jember No. SP. DIPA-042.01.401005/2016 Tanggal 7 Desember 2015, sehingga penelitian ini dapat terlaksana dengan baik.

\section{DAFTAR PUSTAKA}

Almatsier, Sunita. 2010. Prinsip Dasar Ilmu Gizi. Jakarta : Gramedia Pustaka Utama. p : 72104

Arisman. 2010. Obesitas, Diabetes Mellitus dan Dislipidemia. Jakarta : Penerbit Buku Kedokteran EGC, $\mathrm{p}: 1-42$

Badan Penelitian dan Pengembangan Kesehatan. 2013. Laporan Hasil Riset Kesehatan Dasar (Riskesdas) Indonesia tahun 2013. Jakarta: Departemen Kesehatan Republik Indonesia.

Bandini, Linda; Flynn, Albert; Scampini, Renee Scampini. 2015. Gizi Lebih. Dalam Susan A. Lanham-New, Metabolisme Zat Gizi Edisi 2. Jakarta: Penerbit Buku Kedokteran EGC, $\mathrm{p}:$ 339-355.

Berdanier CD; Dwyer JT; Feldman EB. 2008. Handbook nutrition and food 2 nd Ed. USA: CRC Press, Taylor and Francis Group.

CDC. 2011. Body Mass Index: Considerations for Practitioners. Retrieved November 17, 2013, from Centers for Disease Control and Prevention:http://www.cdc.gov/obesity/dow nloads/bmiforpactitioners.pdf

Depkes RI. 2009. Riset Kesehatan Dasar (Riskesdas) 2009. Jakarta : Badan Penelitian dan Pengembangan Kesehatan.

DeBruyne, L Kelly, Pinna, Katrhyn; Whitney, Eleanor. 2011. Nutrition and Diet Therapy Principles and Practice Nine edition. USA : Wadsworth.

Effendi, H. Yekti. 2013. Patofisiologi Gizi: Regulasi Makan, Gangguan Homeostasis Energi, Peran Zat Gizi Pada Pertumbuhan dan Perkembangan Otak. Bogor : IPB Press

Gibson, Rosalind. 2005. Principle of Nutritional Assesment. New York: Oxford University Press Inc.
Goran MI, Sothern M. 2006. Handbook of pediatric obesity: etiology, pathophysiology and prevention.USA: CRC Press

Guyton, AC; Hall, JE. 2010. Buku Ajar Fisiologi Kedokteran edisi 12. Jakarta: EGG, p : 913928

Hanif B. S; Gani ; Djon Wongkar; Shane H. R Ticoalu. 2013. Perbandingan Kadar Kolesterol High Density Lipoprotein Darah Pada Wanita Obes Dan Non Obes. Jurnal eBiomedik (eBM), Volume 1, Nomor 2, Juli 2013

Hastuti, dkk. 2011. Obesitas dan Hubungannya Dengan Polimorfisme Gen Promotor 5HT2A, takanan darah, profil lipid, kadar glukosa darah dan malondialdehid. Jurnal Gizi Klinik Indonesia No.2 Oktober 2011

Heryudarini, dkk. 2005. Penggunaan Berbagai Cut-Off Indeks Massa Tubuh Sebagai Indikator Obesitas Terkait Penyakit Degeneratif Di Indonesia. Jurnal Gizi Indonesia No.31

Hidayat, Burhan. 2008. Obesitas Pada Anak. Surabaya : Divisi Nutrisi dan Penyakit Metabolik Bagian Ilmu Kesehatan Anak Fakultas Kedokteran Universitas Airlangga.

Jorgensen; Knut, B. Johnsen; Bjerregaard, Peter. 2006. Lifestyle modified obesity-associated risk of cardiovascular disease in a genetically homogenous population. Am $J$ Clin Nutr July : 84(1) : 29-36

Kartika, Suryaputra; Siti, R. Nadhiroh. 2012. Perbedaan Pola Makan Dan Aktivitas Fisik Antara Remaja Obesitas Dengan Non Obesitas. MAKARA, KESEHATAN, VOL. 16, NO. 1, JUNI 2012: 45-50

Kemenkes RI. 2013. Tabel Angka Kecukupan Gizi 2013 bagi Orang Indonesia. Tersedia dalam: http://gizi.depkes.go.id [Diakses tanggal 20 November 2016]

Laurentia, YS. 2012. Dislipidemia pada Obesitas dan Tidak Obesitas. Semarang: Fakultas Kedokteran Universitas Diponegoro.

Mestuti, Kinanthi dan Fitranti DY. 2014. Faktor Risiko Kejadian Overweigth Pada Anak Stunting Usia Sekolah Dasar Di Semarang Timur. Journal of Nutrition College Vol. 3 No. 1.

National Heart, Lung, Blood Institute (NHLBI). 2004. ATP III Report on High Blood Cholesterol. Available from : https://www.nhlbi.nih.gov/guidelines/choles terol/atglance.pdf

Sastrosasmoro S, dkk. 2011. Dasar-Dasar Metodelogi Penelitian Klinis Ed.4. Yogyakarta : CV.Sagung Seto. 
Seidell, J.C., Visscher, T.L. 2009. Aspek Kesehatan Masyarakat pada Gizi Lebih. Dalam Gibney, M.J., Margetts, B.M.

Kearney, J.M., Arab, L. Gizi Kesehatan Masyarakat. Jakarta: Penerbit Buku Kedokteran EGC p : 203.

Soegih, Rachmad; Wiramihardja, K. 2009. Obesitas Permasalahan dan Terapi Praktis. Jakarta: CV Sagung Seto.

Sudoyo. 2009. Buku Ajar Ilmu Penyakit Dalam, jilid II, edisi V. Jakarta: Interna Publishing.

Sugondo S. 2007. Obesitas. Dalam : Sudoyo Aru W, Setiyohadi B, Alwi I, Simadibrata M, Setiati S, editors. Buku Ajar Ilmu Penyakit Dalam Ed.4. Jakarta: Interna Publishing

Subramanian, S. 2011. Hypertriglyseridemia Secondary To Obesity And Diabetes. Ciochimica et Biophysica Acta.

World Health Organization (WHO). 2011. Obesity and Overweight. Available from : http://www.who.int/mediacentre/factsheets/f s311/en/ [diakses 23 November 2016]

World Health Organization (WHO). 2013. Obesity and Overweight. Available from : http://www.who.int/mediacentre/factsheets/f s311/en/index.html [diakses 25 November 2016]

Zelzer, Sieglinda et al. 2011. High Density Lipoprotein Cholesterol Level Is A Robust Predictor Of Lipid Peroxidation Irrespective Of Gender, Age, Obesity, And Inflammatory Or Metabolic Biomarkers. Clinica Chimica Acta 412, $p$ : 1345-13 